\title{
Translation Idea: What Is Under-appreciated by a Teacher of Scholar
}

\author{
Wensheng Deng \\ Dept. of Foreign Languages, Beijing Institute of Petrol-chemical Technology, China \\ Ke Zhang \\ Dept. of Foreign Languages, Beijing Institute of Petrol-chemical Technology, China
}

\begin{abstract}
The time of "China's culture going to global" has new idea for a translator, which refers to that translation is supposed to both highlight Chinese culture and to be readily accepted by others. Drawn on particular part of translation history dating back from Ezra Pound to Howard Goldblatt, first, the paper has explored translation paradigm, strategy and relations centered on translation idea. And then, an intermittent line hidden beneath the translation could be sketchily found in subsequent order: poem-composing upon the original image, national-character-reforming by relying on foreignization, Chinese-culture-transmitting on ST-oriented, Chinese-culture-introducing on TT-oriented, and Chinese-culture-transmitting on writer-translator-receptor balance. They have given rise to various paradigms and strategies in translators' practice respectively; corresponding with the ideas, the paradigms could be roughly as: monadism, i.e. one-pole oriented, dualism, two-pole oriented and tri-party negotiated, three-poled. Third, among the three patterns: writer-, translator- or receptor-oriented, writer-receptor-oriented and tri-party-negotiated, writer-translator-receptor-oriented, the first two are a kind of problematic, judged by either cultural theory or conventional one; the latter, relatively speaking, is well balanced up to today, which is recognized by three parties. Regrettably, some unfair interpretations or criticism usually fall upon the works translated before translation ideas are made clear. In the end the author suggests that translation idea not be under-appreciated and a historical perspective be a must for scholar to appraise.
\end{abstract}

Index Terms - translation idea, translation paradigm, historical perspective, translation strategy

\section{INTRODUCTION}

At present, we are faced with a new era in history, which is characterized by turbulence and chaos, unknown to the world in the past century. (Xi Jinping's quotation) Under such a circumstance, all kinds of challenges and crises, either conceivable or unconceivable, are certain to occur to us; so will great changes take place to science and research. Without any deny or doubt, new change and situation will inevitably affect translation studies and practice in the new era. In the new millennium $-21^{\text {st }}$ century, together with the new era "China's culture going to global" strategy, is a new power to push the changes, at least, in two folds. That is, on one hand, some new understanding or concept of translation is about to come into being; on the other hand, obviously, translation mode is to be greatly changed as well. The understanding and concept of translation include nature, idea, strategy, type, and the like in translation; the new mode refers to new existence of translation, for example, machine or online translation, which is being brought into full play in translation practice, primarily because of acceleration of artificial intelligence and economic globalization. Therefore, to most of translators or interpreters home and abroad, machine or machine-aided translation is a normal performance and operation, no more a novel story at all, which was like a shy teenager hiding behind a chamber curtain if discussed in public. To us Chinese, among the waves of continuous changes, we have to admit that there is an event in history: i.e., Mo Yan has gained 2012 Nobel Prize for Literature, which has stimulated us to rethink of translation, particularly literary translation. The event is not only the first time in history of literary translation in China, but also supposedly earth-breaking in national history of China. We have to recognize that, though Mo Yan is a writer of great works, he is not capable of composing his works in foreign languages. Even if so, he were skillful just in English, he would not have required ability to be a creator of his popular pieces. Understandably, every scholar, who is curious about the event, and has paid attention to Mo Yan, will turn his eyes to a translator, Howard Goldblatt, who is regarded as "No. 1 translator for Mo Yan" (Huijun Sun, 2016, pp.31) and "a midwife for Mo Yan's acceptance of Nobel Prize". (Michael Orbach, 2012, OL)

Thus, not only literary field, but also translation one, has shifted their eye from Mo Yan to Howard Goldblatt, and they have shown great interest to him. Even there are scholars home and abroad, who have claimed that Howard is a great push and help for Mo Yan to get the Prize. The implied meaning is that Howard's translation is better than the original. Like Wolfgang Kubin, a German Sinologist, he indicated that Mo Yan would not have gained the Prize without Howard's translation; Wang Ning, a scholar from Tsinghua University of China mainland, had the similar voice with Wolfgang. (Huijun Sun, 2016, pp.36-38) The different arguments have proved that Howard has caused thousands of 
ripples in related academies as a stone is tossed into a lake. Fortunately, people certainly agreed that Howard is a great translator, which is self-evident for him with Mo Yan's recognition of the Prize. Inevitably, the scholars are concerned with questions like: What kind of translation has he contributed to Western readers? What idea is adopted in his translation? What methods has he employed in his translating action etc., to finally bring about such an ideal stage, because Mo Yan's Prize is not merely a personal achievement, but a dream of Nobel Prize chased by every average Chinese for generations?

The questions are very sharp and critical. However, the paper is just to concentrate upon translation idea for his limited scholarship. Based on pivot of idea, it intends to explore relations between idea and translation, referred to the work and the action combined together as a part. Citing some cases in point as examples, such as Hsien-yi Yang and Gladys Yang, his wife, David Hawks and John Minford, Ezra Pound and Howard Goldblatt, mentioned just a few, who are prominent in translation circles, the author is about to make analysis of their translation idea and works. He hopes to find a clear corresponding construct between idea and translation, which is regarded to be underpinning throughout translation practice. Thus, we can better understand the related cases and clarify some misunderstandings about the translators.

\section{LITERATURE REVIEW}

Translation idea, as a link of translation system, not only is a core center of translation studies, but also a focus of academic studies, which has aroused keen interests from related circles, like literature, mainly referred to comparative literature and foreign literature, linguistics, studies of media and communication in China, etc. Only citing translation studies as an example, the author of the paper has got papers and articles related to it as many as 143 pieces in total, dated from 2000 till 2019 by inputting "translation idea" as key words to search on CNKI. ${ }^{1}$ Among them, there are 116, whose titles are connected directly with "translation idea", 22 with "translation strategy", and 5 with "translation concept". The following table provided by CNKI can roughly illustrate distributions of the published papers. ${ }^{2}$

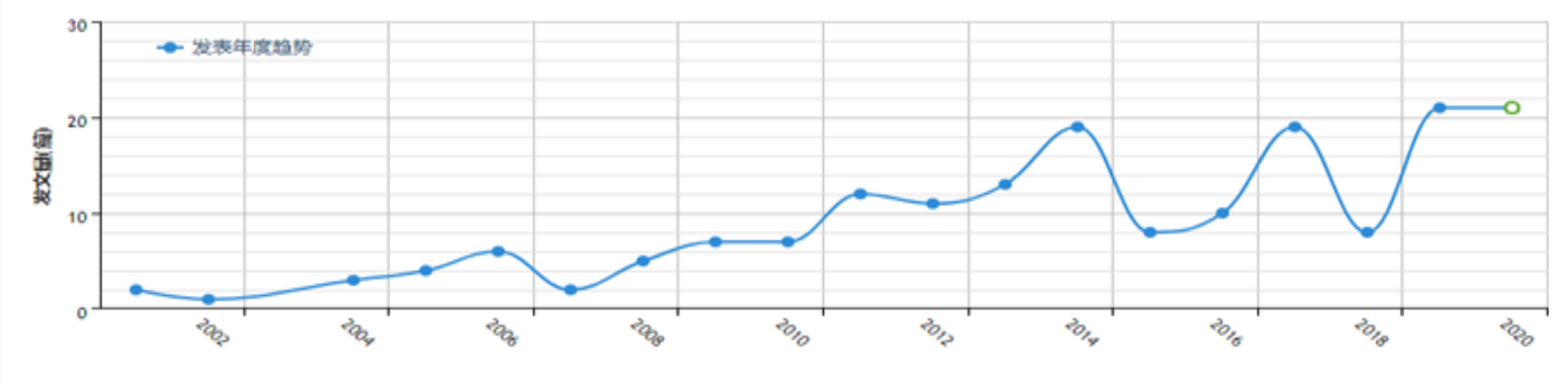

The vertical axis refers to paper volume; the horizontal axis is time measured by year.

The data of the table above-given indicate that the paper output is a kind of rising trend, seen from a viewpoint of the time span. Especially, from 2010 onwards, yields of the paper related with the studies have out-broken bottle neck of the research and got harvest year by year. But, there are just 6 in-depth papers, represented by Professor Xie Tianzhen and Liu Yunhong respectively, (Yunhong Liu,ed., 2019, pp.302-303)which have squarely carried out research of the idea; others have digressed and diverged away from the core concept of translation idea, mistaking or taking it as translation theory, standard or system for granted.

As to foreign data, so far, the author of the paper has not found exact materials targeted at the idea yet, only finding there are papers and theses discussing translation studies in general, like discussion from translation standard, culture, political or sociological turn, etc. The data have reflected that scholars with different backgrounds have different focuses on translation studies. Naturally, Chinese are more dedicated to Howard; but, for foreigners, not much concerned with MoYan's acceptance of Nobel Prize, they are just committed to translation scholarship in a broader manner, whose attitudes to the event are exposed differently here.

\section{IDEA OF TRANSLATION AND WORKS TRANSLATED}

\section{A. Definition of Translation Idea}

Idea, derived from Greek word eidos, meaning visible form, is a notion stretching all the way from one pole, where it denotes a subjective, internal presence in the mind, somehow thought of as representing something about the world, to the other pole, where it represents an eternal, timeless unchanging form or concept: the concept of the number series or of justice, for example, thought of as independent objects of enquiry and perhaps of knowledge. These two poles are not distinct meanings of the term, although they give rise to many problems of interpretation, but between them they define

1.CNKI is the abbreviation of China National Knowledge Infrastructure.

2. See the reference: https://www.cnki.net, 2020/3/13. 
a space of philosophical problems. On the one hand, ideas are that with which we think, or in Locke's terms, whatever the mind may be employed about in thinking. Looked at that way they seem to be inherently transient, fleeting, and unstable private presences. On the other hand, ideas provide the way in which objective knowledge can be expressed. They are essential components of understanding, and any intelligible proposition that is true must be capable of being understood. Plato's theory of forms is a celebration of the objective and timeless existence of ideas as concepts, and in his hands ideas are reified to the point where they make up the only real world, of separate and perfect models of which the empirical world is only a poor cousin. This doctrine, notable in the Timaeus opened the way for the Neoplatonic notion of ideas as the thoughts of God. The concept gradually lost this other-worldly aspect, until after Descartes ideas become assimilated to whatever it is that lies in the mind of any thinking being. (Simon Blackburn, 2000, pp.183)

Obviously, the foregoing interpretation of idea is a philosophical dimension, which is regarded as the origin of derivative connotations of idea. In the interpretation, there are quite a few items adopted by translators as well. First, it is one pole in mind to represent the other pole in the world. It is "an eternal, timeless unchanging form or concept". (Simon Blackburn, 2000, pp.183) Second, it can be taken as a guideline to translation, for "it can provide the way in which objective knowledge can be expressed". Third, it has developed the equivalent to form, which is the ultimate end of Plato's theories. In Plato's eyes, all is fake, or an imitation game of idea except idea itself. Here, the three essential aspects, summarized by the author of the essay, will be used as his theoretical instrument or ground in the following analysis.

Accordingly, the Contemporary Chinese Dictionary (Fifth edition) gives its explanations to "idea":1.belief, e.g. belief in life, 2.thought, concept, notion, e.g. business belief, belief in culture. ${ }^{3}$

Therefore, basing upon the above-given analysis, both Chinese and Western one, we can draw a rough outline for translation idea though arguable. It is a guideline, principle, ultimate goal or a program of action for a translator in his/her practice. It is only partially similar to the definition of translation, but is more than that, which is a core constituent of translation idea. What translation idea a translator has is tied closely with his works translated. The work represents translation idea. It is a king to dominate other subjects in translation. An idea of translation should be inclusive, open and changeable with changing situation.

\section{B. Translation Idea Underlying Translation Practice}

Translation and interpretation have a long history in river of human civilization. In West, if we date back to Mesopotamia era $(3,500 \mathrm{BC})$, translation and interpretation were prevalent just because of national migration and communication. Meanwhile, there are more than five thousand years in China. (Deng, Wensheng, 2020, pp.58) And a translator or an interpreter got its different names or titles at different directions of old China. According to the Zhou Rite (Zhouli),

"...the people living in the five regions spoke different languages and had different customs, likings and preferences. In order to make accessible what was in the minds of different peoples, and in order to make their likings and preferences understood, there were functionaries for the job. Those in charge of the regions in the east were called ji (the entrusted; transmitters); in the south, xiang (likeness-renders); in the west, Didi (they who know the Di tribes); and in the north, yi (translators or interpreters)... . " (Martha Cheung, tran., 2006, p.46)

The document quoted above proves that translation or interpretation is a big player in Chinese civilization throughout history of China, especially in transnational communication and crossing-culture. The peoples in different regions, who speak different languages, can also interact by resorting to a translator or an interpreter.

During the process of interaction every nation has gained its own classics in translation, like Holy Bible in West civilization and The Diamond Sutra in Chinese one, which were and are influential upon respective cultures. The Bible has its significant effects on major languages, i.e. English and German, national character and national unification in Europe; so is the Diamond Sutra upon seeking after a spiritual relief, word-formation in China after the Tang Dynasty (618-907). Interestingly, both the classics are religious, one for Christianity, one for Buddhism. Needless to say, they are great tributaries of the river in civilization. Translation has enriched the world culture and civilization greatly. It is a kind of shaping force in human history. From the history, we may conclude that, first, receptor-oriented idea is to communicate among multiple parties; second, author-oriented idea is to bring about a new culture to others. In short, what purpose decides what idea to hold and what strategy to adopt.

Likewise, such similar phenomenon never stops. Not only it happened in ancient time, but also it did in modern era. And it does give rise to vital significance, whether in West or in China. We can pick up some cases to illustrate the point. For instance, Ezra Pound (1885 - 1972), he was just a good case in point. T. S. Eliot (1888-1965), a British American poet, who accepted Nobel Prize in Literature in 1948, addressed, “...it is an Imagist Group in 1910 in London, which was conveniently regarded as the starting point of modern poetry." As we are clear that Ezra Pound is one of the founders, to some extent, we may declare that it is Pound who has opened up modern poetry in the West. The poetry began to be filled with too much tears, too emotional and insincere after Romanticism, with too many conventions and restrictions after Symbolism. Poets were not satisfied with the current situation and strived to make changes about it. Pound is the only lucky dog who made it work. Probably between 1911 and 1912, he made acquaintance with Allen

3. The Contemporary Chinese Dictionary (xiandai hanyu cidian, fifth edition) is compiled by Dictionary Department, Institute of Linguistics, Chinese Academy of Social Sciences, Peking: Commercial Press, 2005, pp. 826. The English translation is done by the author of the paper. 
Upward (1863 - 1926), a poet and translator, who introduced Pound to read some translations by Herbert. A. Giles (1845-1935), English scholar of Chinese language and culture. After reading his work A History of Chinese Literature, Pound fell into his life-long admiration of Chinese culture. Unfortunately, he was blind to Chinese at all. At the right time, Pound happened to get the manuscripts written by Earnest Fenollosa (1853-1908), American Japanese scholar of Chinese culture, he was especially interested in one of the papers, tilted The Chinese Written Character as a Medium for Poetry. After his seemingly mysterious contact with Chinese culture and literature, mainly classical poetry, Pound formed his China's Complex forever by reading, meditation, forming new thoughts of poetry. He learned Chinese characters in hieroglyphics. And far better than that, he started to translate Chinese classical poetry, mainly the Tang Dynasty (618-907) poetry. His masterwork of the translation is Cathay published in 1915. Here is an example as following:

Liu Ch'e

The rustling of the silk is discontinued,

Dust drifts over the court-yard,

There is no sound of foot-fall, and the leaves

Scurry into heaps and lie still,

And she the rejoicer of the heart is beneath them:

A wet leaf that clings to the threshold. ${ }^{4}$

If we compare Pound's translation with the original Chinese, we may find that, neither just the afore-cited is a translation at all, nor is his Cathay in the least if examined by the criteria "faithfulness" or "equivalence" and the like. But, what is to our surprise is the work enjoyed high popularity among Western readers. Based on his conclusions from translating and studying Chinese poetry, Pound pronounced three principles in writing a poem: First, direct treatment of an object, whether it is subjective or objective; second, absolutely, don't use any word which is no help to representation; third, as regarding rhythm: compose in sequence of the musical phrase, not in sequence of the metronome. Later, the principles were adopted and extended to six articles by American poetess Amy Lowell(1874_1925), another founder of Imagism. What she added her new three principles to Imagism are: First, present an image, treat a specific one with accuracy, and don't deal with them by using some ordinary images in an ambiguous way; second, compose a hard and clear poem rather than a boundless one; third, conciseness and compactness are soul of poetry. Coincidently, the six ideas of Imagism poetry were written down by a Chinese scholar, Hu Shih (1891-1962), from a piece of newspaper in 1915, who was further studying in America. (Xiangyu Liu, Hengda Yang \&Yanbing Zeng, 2008, pp.72-77) Debatably, $\mathrm{Hu}$ adopted and applied the Imagist statement to New Culture Movement in early 20th century in China. Hu's new proposals were influential on the Movement. Without exaggeration, it is New Culture Movement that has led Chinese language, literature and national character to radical changes, i.e. modernization and revolution in society, which was uncompromising in its opposition to feudal culture; there had never been such a great and thoroughgoing cultural revolution since the dawn of Chinese history.

From the discussion given-above, we see what Pound had done was innovative writing instead of translation, specifically, only a rewriting based upon the original image. His strategy is domestication, for whose action was reader or TT-oriented, instead of author or ST-oriented. He had aimed to make a new mode of poetry by reforming traditional poetic writing and borrowing Chinese culture. Additionally, for he knew little about Chinese, understandably, his translation is just a kind of bold imagination of the classical Chinese poetry. As a poet, his genius of imagination helped him grasp and grip with the images in the poetry, which is a core, an essential part in a poem. That is to say, his idea of translation is to get image from the original first. Therefore, the translation, which Pound has accomplished, merely offers us with the original images in his understanding and vision. If we haven't made clear about his translation idea or principle, we will easily give unfair remarks upon them, and say they were poorly rendered indeed. So doing, it is really unfair to him. But, if we could examine the event historically or comprehensively, we would have been more rational to him. To certain degree, we Chinese of today might even be grateful to his wrong-doings in translation, for his Imagist idea, inspired from his translating the poetry, has benefitted a lot New Culture Movement in a way around.

Similarly, on translation there is another case of Lu Xun (1881-1936), both a writer and translator, misunderstood and mistreated by numbers of scholars. As to his writing in Chinese, it is influential on modern Chinese, who is universally regarded as the top of 100 hundred modern writers in China; he deserves the greatest remark. However, when it comes to his translation, whenever he was alive or dead, he was and is always heatedly argued. In his life time, his translation gave rise to numerous quarrels, the most intensive and influential ones, such as his quarrels with Zhao Jingshen (1902 - 1985), writer and professor of Fudan University, with Liang Shiqiu (1903 - 1987), outstanding writer and translator; the names of opponents can last but just mention a few of them. Both sides, one is headed by Lu Xun, the other by his opponents, had denounced the rival of one's own for his translation is full of problems, unfaithful, unreadable, misunderstanding and the like. Furthermore, up to the date as late as $21^{\text {st }}$ century, the unfair treatment about $\mathrm{Lu}$ Xun's translation is still prevalent, which is even claimed by some big potatoes of scholars in China. The famous scholar admits and assumes that Lu Xun's writing is great, first rank and rate among the world, unfortunately, his

4.See the original Chinese here, 《落叶哀蝉曲》 罗袂兮无声, 玉樨兮尘生。虚房冷而寂寞, 落叶依于重肩。望彼美之女兮, 安得感余 心之未宁? 
translation is unreadable, full of simple misunderstandings of the original, and his proposal of replacing Chinese characters by using alphabetic language is too radical and ridiculous. ${ }^{5}$ Without deny, the so-called errors to Lu Xun's translation are acceptable, neutral and objective, judged from present day perspectives; his translation is not classical as his writing. But, here, the scholar made a big misunderstanding about Lu Xun, and he is not aware of that in the least; that is, he has forgotten specific history to talk about Lu Xun. It is a common sense for any one, nothing to say for a scholar, to talk about something in history, especially, to make a comment on a giant like Lu Xun. It is proper and objective to judge anything in context and history. In my eyes, Lu Xun is, of course, conscious of his unique translation. It is just his idea that led him to doing so purposefully. Probably, we know that whatever he had strived to do in his life is to reform Chinese national character. So, his writing and translating were merely used as tools to fulfil his noble end. To Lu Xun eyes, Chinese culture, including Chinese language, is supposed to be reformed or replaced by a kind of new culture. At the time, the new culture was embodied by West powers, which were much more superior to China; every intellectual of patriot would easily turn his eyes to them in order to remodel old China. Lu Xun's hard translation, by employing calqued translation, (Jean Delisle, 1999, pp.123-124) word-for-word, and foreignization, was to retain and reserve foreign style, order and rhetoric; in brief, he was faithful to the original, author-oriented, his work is hard to read on in an old Chinese way. Lun Xun addressed it, "To keep the original flavor is a channel to bring new expressions and forms into Chinese." "It is preferred to be faithful rather than readable." "At first, reader may feel awkward about the translation, but he is sure to adapt to it after some time." (Lu Xun, 1984, pp.229-244)To today's readers of Lu Xun's translation, his works seem to be very awkward, which is quite different from contemporary translation with polluted Chinese in markets. In Lu Xun he is "visible" (Venuti's quotation) and clear of the original; contemporary translation is mostly motivated by seeking either fame or fortune, whose translator is a green hand both in Chinese and foreign language. On the contrary, Lu Xun, as one of flag-bearers in New Culture Movement, a master of Chinese language, was out of his opposition to feudalism, and transformation of national character. Therefore, to remark on his translation is not enough to focus upon the surface only, but to uncover his translation idea hidden under it, because translation is a “purposeful activity”(Christiane Nord, 1997, pp.11-12). Evidently, Lu Xun's radical translation justifies his translation idea, which agrees with his political ideal too.

So, seen from the criterion of "being faithful to the original", Ezra Pound is no translator, Lu Xun is protrude, visible in his translation, for the readers of Lu Xun even could feel the original syntax, and what about David Hawkes (1923-2009) and John Minford (1946-), translators of The Story of the Stone, which is regarded as classics of Penguin Group. We know that, before The Story of the Stone, there was an edition of The Dream of the Red Chamber co-translated by Hsien-yi Yang (1915-2009) and his wife Gladys Yang (1919-1999). Yang's edition is popular among readers home and abroad. However, after The Story of the Stone was published by Penguin Group, its popularity is rising steadily, especially among Western readers, and was collected by major libraries over the world. When it is republished, it is highly appraised as a classic, which has proved the translation is successful. So, here is the question: why have the two editions resulted in remarkably contrasts? Is it due to Yang's English efficiency as someone has claimed? Obviously not, because Yang was a top student at Oxford University and his wife Gladys was his schoolmate at Oxford. Yang was both versed in Chinese culture and literature and British ones; and Gladys was very familiar with them too. To the field of Chinese translation, their marriage is just a magnificent match, which has rendered numerous volumes of Chinese classics into English. As to David Hawkes and John Minford, they were persistent to study Chinese culture and literature for several decades, and both are teachers of Chinese Department at world-known universities for many years. What's more, they frequently discussed problems encountered with the Yangs in translating Chinese works, which indicates that they have not much problem to understand the culture. Then, we have to make comparisons with the two editions so as to explore the reasons hidden in the phenomenon. As we dig into them, we find that Yang is more faithful, closer to the original in denotation, and formally more equivalent to the original; whereas, Hawkes is faithful to the original in communication and connotation, more faithful to the original in spirit. Yang's strategy seems more to be inclined to foreignization, a kind of author-oriented; perceivably, Hawkes is naturalization, reader-oriented. One example is evident to illustrate what is above-discussed. There is an original Chinese “谋事在人, 成事在天( móushì zài rén, chéngshì zài tiān)".

Yang's version is: Man proposes; Heaven disposes;

Hawkes's is: Man proposes; God disposes.

Here, the distinction lies in their respective rendering “天”. Needless to say, God is a typical code in Western cultures, whatever; majority of the Western readers is not familiar with it any longer; as to heaven, it is just a physical concept to them, which could arouse no more religious connotation in the least. Psychologically, God is dominant, closer to them, but not heaven. Such naturalization can be seen in every line throughout The Story of the Stone. Partially, it could explain why it has been enjoying its great popularity for a long time; and Yang's hasn't so much as that. Similarly, if we have kept an eye on other translation by John Minford, e.g. Strange Tales from a Chinese Studio, ${ }^{6}$ another classic as well, we would have concluded that it reads smooth and feels a kind of natural or native flavor except some strange

5.The scholar is one of host speakers on a conference of translation and literature, sponsored by Beijing International Studies University, in May, 2018. For the sake of privacy, his name is purposely omitted by the author of the paper.

6. Pu, Songling. (John Minford, ed. \& trans.). Strange Tales from a Chinese Studio. Penguin Groups, 2006. 
names. On the contrary, a second version of Strange Tales from a Chinese Studio by Herbert a. Giles is not as welcome as Minford. Readers of Herbert a. Giles feel "it didn't make a sense", a bit confused to read it. And John Minford is recommended. ${ }^{7}$ In fact, Giles, like Hsien-yi Yang and Gladys Yang, adopted a foreignization or estrangement in the work. So, the receptors of Giles of course felt it awkward. From the cases discussed above, we can see the translation idea, held by Hsien-yi Yang and Gladys Yang, is to highlight Chinese culture over the world, as a foremost goal in translation, stipulated by the central government of China, so their strategy is foreignization as a way out. Nevertheless, to David Hawkes and John Minford, they took target-reader into consideration to facilitate understanding other's culture, to shorten the journey between the original and target-text reader, (Ch'ien Chung-shu's remarks) conceivably, domestication is a proper choice. Hence, I suggest that, if we try to let Western readers accept Chinese culture, domestication and reader-orientedness are temporarily preferred though they have disadvantages, i.e. Chinese culture is partially more hidden and transfigured than foreignization and author-orientedness.

Just because many scholars have different voices of their own on translating Chinese classics, they claim that monadism is problematic, which is centralized about single-dimension in process of translation, i.e. taking either author, translator or reader as a foci. The author-oriented model is hard, unreadable for readers to accept; what a translator exhausted his paining efforts gets only sparse responses from his readers, like Lu Xun or Vladimir Nabokov(1899-1977), American novelist and translator as well, they aren't read as much as their writing; the translator-centered is to rewrite the original, which is rebuked by both sides of the process; one criticism is that he is a traitor of the original, the other is he is a liar or a deceiver of the reader because, actually, he has rendered and rewritten the original for them for he has controlled or dominated the original for some reason, as Ezra Pound or Lin Shu (1852-1924), a prolific, problematic and controversial translator in the late Qing Dynasty(1644-1911). Sometimes, some relatively mediocre original work was elevated or exaggerated to be a classic or vice versa by them; a receptor-/reader-oriented tends to bridge the gap between author and reader by effacing the original cultural uniqueness, or to explain and expound the original uniqueness by utilizing reader's culture. No wonder, both sides of the process are not satisfied with him, because the original is transfigured totally, to the receptor, he seems to be cheated for his curiosity of other culture is no true at all. The genres in the translation are far from satisfaction from each part. Inevitably, a third model is required to meet calls of new time.

Eventually, Howard Goldblatt answered the call in a proper time just because what he had translated MoYan made the world recognize. As we say Mo Yan is great for his creative narration in novel text, but his influence would be limited and confined to China without great ferrymen like Howard Goldblatt. In my eyes, he is a representative of new paradigm in translation in the new era, characterized by globalization. According to Roland Barthes (1915-1980), a prominent French thinker, he divided text into two categories: writerly text and readerly text; (Leitch, Vincent B. Cain, William E. Finke, Laurie. \& Johnson, Barbara.et al, eds., 2001, pp.1470-1475) by borrowing the two concepts, I would refer to two kinds of translation correspondingly: writerly translation and readerly translation. The first one means author-oriented, the latter reader-oriented. But, for me, the two concepts are unable to cover Howard Goldblatt square and fair. He has applied a new type of translation to deal with Mo Yan. Here, I reflect Howard upon all what he has done besides Mo Yan, for who is only my foci of forthcoming discussion. Let us take Red Sorghum: A Novel of China as an example to demonstrate his novelty. His creation is "organic unity". It refers to that "Howard Goldblatt always takes his translation as an organic unity, which he views the structure of the translation as a whole to secure the structural faith of the translation to the original. His kind of faith is to adjust the translation's structure, and to make the translation be loyal to the original as a whole, but not the traditional loyalty or equivalence of word-for-word." (Wensheng Deng \& Ke Zhang, 2017, pp.49-54) In the translation, Howard readjusted the original chapters. The original, with only one title "Red Sorghum" capitalized from Chapter 1 to 9 throughout, consists of 9 chapters, with no subtitle. However, the translation Red Sorghum: A Novel of China has only 5 chapters, which aren't equivalent to the original quantity at all. Moreover, it has added a sub-topic to each chapter; they are listed as the subsequent: Chapter 1 Red Sorghum, Chapter 2 Sorghum Wine, Chapter 3 Dog Ways, Chapter 4 Sorghum Funeral, and Chapter 5 Strange Death. Apart from the curtailment and adjustment of the original chapters, Howard Goldblatt has made combinations, changes, revisions and additions to some of the original chapters. He has bravely deleted some ridiculous narration, which, to some extent at one's first glance, seems unacceptable to Western readers. He made original Chapter 4 shorter, and rewrote the original end, etc. In short, compared with the original, the translation has been changed a lot here and there, but, we readers of the translation can hardly feel the changes and gaps between them. On the contrary, at least, structurally, I hold that the translation is loyal to the original; furthermore, the plots of the translation read a little bit smoother than the original; the whole structure is linked more closely to each chapter than the original too. Seen from the instance, the structure and theme are more outstanding upon reading, the content reads more distinctive and logical. Thus, by Western readers' yardstick, they tend to think that the translation is easier for those interested to be accepted than an unadapted one if Howard had. Obviously, Howard has not cracked his brain to only be faithful to word, clause, or paragraph, but structurally faithful to the original text, i.e. a kind of textual loyalty, to convey the original. ${ }^{8}$ Facing

7. This is an excerpt of readers' comment on Giles, see https://www.amazon.cn/dp/B00FVE9WL8, 4/4/2020.

8.For the detailed discussion of structural faithfulness, see Deng, Wensheng. \& Zhang, Ke. (2017). Howard Goldblatt's Three Treaties or Treatments of Translation, Theory and Practice in Language Studies, Vol. 7, No. 1, pp. 49-54, January 2017, DOI: http://dx.doi.org/10.17507/tpls.0701.06. 
the new mode of translation, a bunch of scholars expressed different voices. Some say he has rewritten, abridged or adapted the original, others claim that his translation is better than the original; there are also some opinions that favor with him. All in all, the remarks are like blind men and elephant, who take a part as the whole. They haven't probed into the whole process, which is different from old one. First, it is a product of negotiations between Howard Goldblatt and MoYan, i.e. writer-translator-reader; Howard the translator as a mediator between two poles, it is a triparty-negotiated translation. Howard always gave calls, wrote letters or forwarded emails to ask Mo Yan when he couldn't understand him, and wanted to adjust or rewritten his works. Owing to Mo Yan's open-mindedness and inclusiveness, Howard could always get satisfactory responses. Mo Yan even told Howard, "I don't understand a foreign language, since I entrusted my works to you, they have belonged to you; you can make decisions of your own as you like." (Howard Goldblatt, 2004, pp.26) This is one of the reasons why he made changes or adjustments about Mo Yan. Additionally, under pressure of patronage, publishing house or market benefit, he had to cut off some redundancy in plot development, description and delineation to satisfy Western Poetics or Aesthetics. Second, his translation strategy is quite different from old one. What he has adopted was a combination of domestication and foreignization. Particularly, I would like to point out that, sometimes, his foreignization is to transcribe the original. For instances, “爹(diē)” “娘(niáng)” “衙役 (yáyì)” “员外郎(yuán wài láng)” “老太爷(lăo tài yé)”, he transcribed them by using Pinyin. For the strategy, usually, a translator is worried about receptivity of neologism; Howard explained about it, "I think it is time to update and increase the meager list, and to that end, I have left a handful of terms untranslated; a glossary appears at the end of the book. Only one is given in a form that differs slightly from standard Pinyin: that is "dieh," commonly used for one's father in northern China. The Pinyin would be 'die'! " (Howard Goldblatt, 2013, pp.10-11) His unique mixed strategy retained and reserved the original, highlighted cultural specific items in the meanwhile. What he has most amazed us is he made no annotation, addition to them, they are scattered and embedded through the words, and readers feel natural and native. In short, they are harmonious in proper context. In the New Era of "Chinese Culture Going to Global", such typology of translation can best embody the unique culture and the Western readers are happy to accept. What he has done provides us with an example to transmit Chinese classics towards others. What's more important is, he has rejuvenated English culture by introducing new expression and form, which undertakes the role to cross cultural barriers. If we revisit Howard's translation idea, it is easy for us to understand his bold action in translation, especially in Red Sorghum: A Novel of China. Though he has seldom professed his translation idea, in his talks, interviews and lectures we may still get it at least, "what a translator should be engaged in is to interpret in another field." "...a translator's responsibility is utmost important and very tough to bridge gap between nations and cultures; whether his work is regarded as a craftsmanship or an art, or both; he is a transmitter, an interpreter of the chain to understand other nations internationally, who is one of the main parts in the chain."(Howard Goldblatt, 2016, pp.15) Herein, Howard admits he is "a transmitter, an interpreter of nations and cultures." That is to say, they are his translation idea, ultimate goal. To accomplish his idea, he had to adopt new approaches, a revolution in translation for the old ones, to some extent, are unable to meet the needs of sender and receiver. To Chinese excitement and the world as well, his revolution in translation paradigm help national literature, Chinese one, reach global stage of world literature, (Wensheng Deng, Fuyang Xia \& Li Chen, 2016. pp.79-83) for Mo Yan is recognized by the most influential institution Nobel Prize Committee in Literature.

\section{CONCLUSIVE REMARKS}

By observing a particular part of translation history briefly, we may get some lessons. First, we may roughly see translation ideas underpinning translation. Every one of them was different so it is unfair to comment on him by a consistent and unvaried standard. Historical view is justifiable. Like Ezra Pound, seen from translation standard, he is far from that but manipulation or appropriation of culture; yet from poetic composing, he is revolutionary. Lu Xun, seen from expressiveness, readability or smoothness, he is low, and form cultural renovation, he is great, but he went extremely radical to negate Chinese culture; from public spreading, Hsien-yi Yang and Gladys Yang are very good; from receptivity, David Hawkes and John Minford are none to the second, but comparatively, they subjected the original and catered to his receptors, which is a kind of post-colonial approach; from transmitting Chinese culture or media-translatology, Howard Goldblatt is most successful up to today, even in several decades to come for his better balance between foreignization and domestication. But, objectively speaking, Howard has changed Red Sorghum a lot on plot, end and minor structure though authorized by Mo Yan; probably he was conscious of the behavior after that, he has been returning to traditional pattern step by step. Then, from the history, we say translation pattern is dynamic. It has developed from monadism, i.e. one-pole oriented, dualism, two-pole oriented till tri-party-negotiated, three-poled, which have been pushed forward by ideas desired and derived from history or time. The inter-wined impacts between them are complex and complementary and covered under all kinds of phenomenon. Third, among the three patterns of translation, monadism, writer-, translator- or receptor-oriented, dualism, writer-receptor-oriented and tri-party-negotiated, writer-translator-receptor-oriented, the first two patterns are a kind of problematic, judged by either cultural theory or conventional one; the latter is well balanced up to today, which is recognized by three parties. Therefore, under such complex and confused circumstances, first, either a teacher or a scholar of translation should be clear about translation idea of one's own, then, he could evaluate translation in a historical context of situation, rather than hurry to arrive at some claims. 


\section{REFERENCES}

[1] Black burn, Simon. (2000). Oxford Dictionary of Philosopy. Shanghai: Shanghai Foreign Language Education Press, pp.183-184.

[2] Cheung, Martha. (tran., 2006). An Anthology of Chinese Discourse on Translation Volume 1: From Earliest Times to the Buddhist Project. Shanghai: Shanghai Foreign Language Education Press, p.46.

[3] Delisle, Jean. Lee-Jahnke, Hannelore. \& Cormier, C. Monique. (1999). Terminologie de la Traduction, Translation Terminology, Terminologia de la Traduccion, Terminologie der Übersetzung. Philadelphia: John Benjamins North America, pp.123, 192, 154, 211.

[4] Deng, Wensheng. Xia, Fuyang. \& Chen, Li. (2016). The Approaches from National Literature to World Literature. Theory and Practice in Language Studies, Vol. 6, No. 1, pp. 79-83.DOI:http://dx.doi.org/10.17507/tpls.0601.10.

[5] Deng, Wensheng. \& Zhang, Ke. (2017). Howard Goldblatt's Three Treaties or Treatments of Translation, Theory and Practice in Language Studies, Vol. 7, No. 1, pp. 49-54. DOI:http://dx.doi.org/10.17507/tpls.0701.06.

[6] Editors' Department of Chinese Translators' Journal, Chinese Translators' Association. (eds.) (1984). Anthology of Essays on Translation from1894 till 1948. Peking: Foreign Language Teaching and Research Press, pp.229-244.

[7] Goldblatt, Howard. (2004). "Blue Pencil Translating: Translator as Editor", Translation Quarterly, pp.26-28.

[8] Goldblatt, Howard. (Shi Guoqiang, ed., 2016). Literature and Translator, in Selected Essays by Howard Goldblatt. Peking: Modern Publishing House, pp.8-15.

[9] Leitch,Vincent B. Cain, William E. Finke, Laurie. \& Johnson, Barbara. (et al, eds.). (2001). Roland Barthes. From Work to Text in The Norton Anthology: Theory and Criticism. New York: W.W. Norton \& Company Ltd., pp.1470-1475.

[10] Liu, Xiangyu. Yang, Hengda. \& Zeng, Yanbing. (eds., 2008). From Modernism Throughout Postmodernism. Peking: Higher Education Press, pp.72-77.

[11] Liu,Yunhong. (ed.). (2019). The Studies of Howard Goldblatt's Translation. Nanjing: Nanjing University Press, 302-303.

[12] Mo Yan. (Howard Goldblatt, trans.). (2013). Translator's Note in Sandalwood Death. Norman: University of Oklahoma Press, pp.10-11.

[13] Nord, Christiane. (1997). Translating as a Purposeful Activity: Functionalist Approaches Explained. Manchester (UK):St. Jerome Publishing, pp.11-12.

[14] Orbach, Michael. (2012). "H. Goldblatt: the foremost Chinese-English translator in the world". http://site.douban.com/106369/ widget/notes/134616/note/252321086/, 12/15/2012.

[15] Sun, Huijun. (2016). Howard Goldblatt and His Translation and Promotion of Modern and Contemporary Chinese Fiction. Shanghai: Shanghai Jiao Tong University Press, pp.31-38.

Wensheng Deng was born in Anhua County, Hunan Province of China in 1967. He received his M.A.in literature from Central South University of China in 2002, and he has further trained his academics at Harding University of the USA from 2007 until 2008. And now he is Associate Professor of Anglo-American Literature of the Dept. of Foreign Languages at Beijing Institute of Petrol-chemical Technology, China. His scholastic studies cover Comparative Literature, Translation Studies, Film Studies and Politics.

Mr. Deng is a member of Chinese Association of Foreign Language Teachers. And he has published more than 40 papers home and abroad.

Ke Zhang was born in An Qing city of Anhui Province of China in 1978. She got her M.A.in literature of Russia and linguistics from Capital Normal University of Beijing of China in 2002. She is interested in movie analysis, western culture etc. Current ly she is a lecturer of the Dept. of Foreign Languages at Beijing Institute of Petrol-chemical Technology, China. She has also published lots of papers home and abroad. She is a member of Chinese Association of Foreign Language Teachers. 